\title{
Evaluating the Moral Framing of Disaffiliation: Sociological and Pastoral Perspectives on the Rise of the "Nones"
}

\author{
Brett C. Hoover
}

check for updates

Citation: Hoover, Brett C.. 2021. Evaluating the Moral Framing of Disaffiliation: Sociological and Pastoral Perspectives on the Rise of the "Nones". Religions 12: 386. https://doi.org/10.3390/rel12060386

Academic Editor: Roberto Cipriani

Received: 1 April 2021

Accepted: 25 May 2021

Published: 27 May 2021

Publisher's Note: MDPI stays neutral with regard to jurisdictional claims in published maps and institutional affiliations.

Copyright: (c) 2021 by the author Licensee MDPI, Basel, Switzerland. This article is an open access article distributed under the terms and conditions of the Creative Commons Attribution (CC BY) license (https:// creativecommons.org/licenses/by/ $4.0 /)$.
Bellarmine College of Liberal Arts, Loyola Marymount University, Los Angeles, CA 90045, USA; bhoover@lmu.edu

\begin{abstract}
The wave of religious disaffiliation that began in the 1990s in the United States has gone from $a$ concern of pastoral leaders to perhaps the concern of pastoral leaders. This article examines a moral framing of religious disaffiliation-where disaffiliation is seen as a symptom of larger moral struggles in society. After a review of contemporary sociological research on the phenomenon of disaffiliation, its roots and causes, the article explores the thinking of the influential Catholic bishop and media entrepreneur Robert Barron as an example of the moral framing of religious disaffiliation. Barron operates as a "moral entrepreneur" in today's media-rich context, working to persuade Catholics to eschew certain strains of secular and liberal Catholic thinking in order to embrace traditional Catholicism as part of a moral struggle for the soul of U.S. society. Sociological theory on moral entrepreneurship and moral regulation helps make sense of his position. In the end, however, the causes and processes revealed in sociological research on disaffiliation reveal the moral framing as an inadequate construct for making sense of the actual phenomenon. I conclude by recommending a "historical-pastoral" framing of disaffiliation instead.
\end{abstract}

Keywords: religious disaffiliation; Roman Catholicism in the United States; moral regulation theory; social constructionism; moral entrepreneurs; pastoral responses to religious disaffiliation

\section{Introduction}

Each year graduate students in pastoral theology at the Jesuit university where I teach express their deep concern about the rise of the "nones", that is, those who choose "no religion" on surveys about religious affiliation. I first witnessed such concerns emerging in Catholic ministry contexts in the 1990s, before unequivocal data had emerged. Much of the worry came from older adults and pastoral leaders observing declining religious participation and interest among younger people, though not yet complete disaffiliation. Data from that time confirmed their impressions (Putnam and Campbell 2010, p. 107). While the same trends had long been at work in mainline Protestant communities in the United States, the diminishment came as a shock in U.S. Catholic communities where mass attendance had long been constructed as mandatory. In Catholic young adult ministry in those days, many began to sound the alarm, though some elders simply assumed young people would wander back when they married and had children of their own.

Real statistical evidence for the current wave of religious disaffiliation in the United States became considerably more pronounced through the 2000s, when I began teaching at the graduate level. Among my ministry students I found robust interest in the causes of disaffiliation, including multitudinous pet theories, and I began sharing the tentative interpretations of the data by sociologists, who saw the phenomenon as rooted in generational change, a weakening of social norms about church attendance, and a youthful political reaction to the high media visibility of the Religious Right (Hout and Fischer 2002). But in the last decade, as disaffiliation has shown itself to be widespread and overwhelming, opting out by the "nones" has gone from an issue of interest, or even of urgent pastoral concern, to a perceived existential threat to Catholic parishes, schools, religious orders, and other ministries and organizations. Even groups that had previously seemed impervious to 
disaffiliation-such as Hispanic Catholics or white Evangelicals-began to show signs of it. ${ }^{1}$ By the 2010s, in other words, disaffiliation had gone from being $a$ concern of religious people to being the concern. Gatherings at Fordham University, the Jesuit university in New York City, in 2011 and 2019, capture the changing tenor of the conversation. The earlier conference sported the more tentative title, "Lost? Twenty-somethings and the Church", but the latter was entitled, "Does Faith Have a Future? A Symposium on God, Religion and the 'Nones'".

Such a central concern demands, as my students insist, dramatic pastoral responses, but any effective Christian pastoral response to disaffiliation requires (1) a careful analysis of disaffiliation and its social mechanics, rooted in empirical research; and (2) a pastoral framing of disaffiliation that coheres with that analysis. My contention is that there currently exists an unproductive tension between the historical roots and sociological causes of disaffiliation in the United States, and the moral framing of disaffiliation, where it is seen as a symptom of a dangerous and potentially permanent moral threat emanating from the influence of secular thinking. I recommend instead that pastoral leaders dispense with this moral framing and the moralizing discourse that accompanies it, and frame disaffiliation as a discrete historical problem that can be addressed-though not eliminated-with focused pastoral attention (a "historical-pastoral" framing). In these pages, I begin with a review of existing sociological research on disaffiliation. The next section offers up the thinking of Bishop Robert Barron, an influential Catholic media entrepreneur, who does frame religious disaffiliation as part of a larger secular moral threat, though that framing conflicts with the sociological research just reviewed. To understand this apparent contradiction, I turn to moral regulation theory as it has emerged within the sociological study of moral panics. Finally, I propose an alternative "historical-pastoral" framing of disaffiliation and its implications for ministry.

\section{Disaffiliation in the United States since the 1990s}

Religious disaffiliation is a phenomenon oft observed, but not always well understood by religious leaders. Affiliation to organized faith communities has waxed and waned throughout U.S. history. ${ }^{2}$ There has been no stable, definitive level of religious belonging or participation, and attempts to contrast today's declining affiliation with a golden age of religious affiliation are vulnerable to a fuzzy sort of nostalgia. Existing data do indicate that affiliation and participation in traditional religious institutions reached a provisional peak in the early postwar period, from the late 1940s into the early 1960s, especially among young people. This occurred alongside other markers of social stability (such as marriage rates and fertility) after decades of economic depression and war. Cold War opposition to atheistic communism played a role-traditional religion was patriotic-as did the postwar rise of the "new" Evangelicalism associated with figures like Billy Graham (Putnam and Campbell 2010, pp. 82-90).

By the late 1960s, however, religious affiliation suffered a "shock", an initial decline in affiliation accompanied by a more pronounced reduction in Americans' trust in religious authority and institutions. Finally, religious disaffiliation dramatically accelerated beginning in the 1990s. That last decline is our focus here. For two decades after the late 1960s, even after religious participation had suffered a shock, the non-affiliated population hardly changed at all, remaining about 7\% of the population (Putnam and Campbell 2010, pp. 70-133). Beginning in the 1990s, however, religious disaffiliation proved steady and precipitous. By 2018, social surveys produced estimates of the non-affiliated population ranging from 23\% (General Social Survey) to 31\% (Cooperative Congressional Election Study). ${ }^{3}$ In just under thirty years, the United States went from a country where slightly more than one in fifteen people described themselves as not religious, to one where nearly one in three do. At the same time, the vast majority of the unaffiliated do not describe themselves as atheist or agnostic (though these groups now seem to be growing) but as simply "nothing in particular" (Pew Research Center 2015, p. 14). 
Disaffiliation is real and dramatic. Though the non-affiliated population tends to be younger and more white, male, highly educated, and more politically liberal than the religious population, rejecting religious affiliation reaches into every demographic (Heft and Stets 2021, p. 3). Much of this seems to have emerged through generational changes. According to Pew Research Center data from 2014, 11 to $17 \%$ of those born before 1964 say they have no religion, while 34 to $36 \%$ of those born after 1981 say the same. But each one of these generational groups also grew less religious from 2007 to 2014 (Pew Research Center 2015, p. 12). Another factor to keep in mind is what sociologists call "social desirability bias", that is, that people are likely to overreport associations and behaviors they think other people see as morally upright (Burge 2020, pp. 176-77). This likely means that the survey data on religious affiliation from earlier decades might underreport the number of unaffiliated persons, though as social pressures among young people have more recently turned against religious affiliation, young people may actually be overreporting their lack of religious affiliation.

There are limitations to what survey data tell us, of course. Survey questions generally avoid ambiguities about what religious belonging means in different social, cultural, and religious contexts. For Hispanic or Filipino Catholics, for example, religion and culture are difficult to disentangle, and non-institutionalized popular religious practices are commonplace. In African American communities, religion is part of a history of safe havens and resistance to racism. Very few in older generations simply disavow it, though the situation seems different among younger Black Americans, who still, nevertheless, have an overwhelmingly positive view of the role of the Black Church in the community. ${ }^{4}$ For many immigrants from East Asia, communism made explicit religious affiliation suspect, but religious practices have endured, though understood more through the lens of culture. Education and social class also matter in disaffiliation. Sociologist Nancy Ammerman found more conservative religious beliefs (such as a commitment to a more literal view of biblical inerrancy) among both the religiously affiliated and religiously unaffiliated among Americans with fewer years of education, and she found a consistent rejection of such beliefs among highly educated Americans, religious or not (Ammerman 2021, pp. 28-39).

Finally, some scholars argue that conceptualizing these changes as "disaffiliation" already assumes that religious belonging is homogeneous or normative, in effect making the high conformity religious commitment of the 1950s uniquely prescriptive. These scholars advocate instead for viewing the trend in terms of "de-conversion", attending to the circumstances and psychological processes by which people gradually (and often ambiguously) sever their ties with religious communities. ${ }^{5}$ To at least some proponents of the deconversion model, a "secularizing exit" rejecting religious affiliation entirely is only one possible form of deconversion alongside others, that could include, for example, a "privatizing exit" where people continue to practice but eschew formal membership, or switching to a more countercultural affiliation such as a fundamentalist sect, termed an "oppositional exit" (Streib et al. 2009, pp. 26-28).

Despite these complicating factors, there is remarkable consensus among sociologists as to why religious disaffiliation since the 1990s has surged. The change seems largely the result of change across generational cohorts. A short conversation in any one of my undergraduate classes illustrates the point-they go out of their way to identify themselves as not religious, especially in front of peers. In contrast, back during the 1950s, people with little interest in religion — such as my grandparents—still felt a social need to identify themselves as religious. Today, few people see any point in pretending to be more religious than they are. Another factor is that more people in recent decades have been raised in non-affiliated homes, products of the declining influence of religion beginning during the late 1960s. ${ }^{6}$ Other factors that potentially have had an impact on disaffiliation include spiritual struggles, religious skepticism in general, and certain kinds of personal crisis (e.g., financial ones). ${ }^{7}$

But perhaps the most dramatic part of the story of disaffiliation, though only a part, has to do with political affiliation. About a decade after the trend toward choosing "no 
religion" had accelerated, sociologists Michael Hout and Claude Fischer noted that religious disaffiliation arose just as the Religious Right was at its zenith in terms of public influence. They offered a theory: "The growing connection made in the press and in the Congress between Republicans and Christian evangelicals may have led Americans with moderate and liberal political views to express their distance from the Religious Right by saying they prefer no religion" (Hout and Fischer 2002, p. 168). Liberal people reacted to noisier Christians proclaiming strong ties between conservative politics and faith by moving away from religion entirely. To back up their claim, Hout and Fischer analyzed General Social Survey data that showed how politically liberal people had become less religious while more conservative people had not changed in their religious affiliation. Sociologist Nicholas Vargas has observed, however, that Hout and Fischer "did not actually examine whether disagreement toward religious political involvement was associated with identification as a religious none in multivariate analyses" (Vargas 2012, p. 203).

In 2010, the political scientist Robert Putnam and the sociologist David Campbell made a larger historical argument about disaffiliation, first drawing attention to a short rise in religious affiliation and participation during the 1980s, likely in response to the radical challenges to authority and more liberal sexual ethics that arrived in the late 1960s and 70s. This increase in religious affiliation and participation initially included many younger people, and it favored Christian Evangelicalism. During the 1980s, for example, Evangelical fellowship groups gained a certain prominence on U.S. college campuses. But by the 1990s even Evangelicals began to lose young members, and many groups of young people consciously distanced themselves from a religion they viewed as unacceptably conservative (Putnam and Campbell 2010, pp. 100-20). Echoing Hout and Fischer, Putnam and Campbell point out, "Young Americans came to view religion, according to one survey, as judgmental, homophobic, hypocritical, and too political" (Putnam and Campbell 2010, p. 121).

Putnam and Campbell further note how more Americans began to object to religious leaders' political activity, but then they focus in on dramatic changes in young people's attitudes toward homosexuality, and toward the legalization of same-sex marriage in particular. More liberal attitudes in these areas-along with a more positive view of marijuana-exploded at the same time that religious disaffiliation increased dramatically. Indeed, Vargas found support for same-sex marriage positively associated with both considering and following through on disaffiliation, and he suggested that specific political positions in conflict with religious ideals may be a major catalyst for disaffiliation (Vargas 2012, pp. 203-4, 213-14). In short, both Putnam and Campbell and Vargas point to gay marriage as a wedge issue that has pushed people away from religion (Putnam and Campbell 2010, pp. 120-33). While Putnam and Campbell do not discuss this, it is surely no coincidence that at this same time Catholic bishops of the United States began to ally themselves more visibly with Evangelical objections to same-sex marriage.

In 2014, Hout and Fischer conducted an updated analysis of survey data which affirms the trajectory of this argument. They also establish, however, that by the early 2010s, generational change had become the driving factor in religious disaffiliation. What Hout and Fischer did not find any evidence of is that the trend toward disaffiliation was shaped by larger societal pressures toward secularization (Hout and Fischer 2014, pp. 442-44). As Putnam and Campbell point out, "Because the rise of the new nones was so abrupt, this increase seems unlikely to reflect secularization in any ordinary sense, since theories of secularization refer to developments that transpire over decades or centuries, not just a few years" (Putnam and Campbell 2010, p. 127). Indeed, scholars who emphasize the broad secularization approach of scholars like Charles Taylor have to resort to additional factors-such as a radical sharpening of individualism or consumerism-to account for the rapid onset of disaffiliation. ${ }^{8}$

Another major source of data on disaffiliation is the non-profit Pew Research Center. A 2019 report on telephone surveys from 2018 and 2019 placed the unaffiliated as $26 \%$ of the U.S. population, but $40 \%$ of persons in the Millennial generation. That same report estimated that Catholics were no longer a majority among Hispanics, and that 
nearly a quarter of Latinx people in the United States reported no religious affiliation (Pew Research Center 2019, pp. 3-15). Pew has also engaged in smaller, representative quantitative or mixed method studies that have attempted to explain the reasons behind disaffiliation, often by developing categories or ideal types rooted in the reasons people articulate for disaffiliating. Pew split the non-religious population into "Solidly Seculars", who reject all religious beliefs, and "Religion Resisters", who see themselves as spiritual but find organized religion a negative force (Alper 2018). Another Pew study tested various distillations of explanations people had offered in previous research and disaggregated them by whether respondents identified as atheist, agnostic, or "nothing in particular". The highest numbers came in for questioning religious teachings $(60 \%)$, not liking the social/political positions of churches $(49 \%)$, and simply not liking religious organizations (41\%), findings consistent with the research already described (Pew Research Center 2018). In short, while the interpretations of Hout, Fischer, Vargas, Putnam, and Campbell hold up, it is also clear that there are in the end many reasons why people reject religion. Christel Manning affirms this last point in her book on non-religious people and parenting; unaffiliated people actually represent a broad variety of views regarding religion and spirituality, only some of which can be classified as secular (Manning 2015, pp. 5-6, 26-49).

\section{Moral Framing of Disaffiliation}

Religious disaffiliation in the United States is real, dramatic, generational, and stirred at least in part by specific historical factors, most visibly political polarization over issues like same-sex marriage. But the reasons and ways people leave are also varied and complex. And just as there is no single experience of disaffiliation, neither are we likely to find a monolithic interpretation of the phenomenon, even among theologians or religious leaders. Indeed, some see disaffiliation as simply one sign of young people "making do with religious subjectivity in a pluralistic, consumer culture" (Beaudoin 2013, p. 259), or one outcome of the modern limits to religious authority that produce an "interpretive autonomy" in response to religious teaching and tradition (Dillon 2018, p. 6). Others take a more practical approach: as the practical theologian James Michael Nagle notes, "The assumption has been that disaffiliates and their experiences represent a problem that must be solved. They have 'fallen away.' They are 'lapsed.' They are 'nonpracticing' Catholics" (Nagle 2019, p. 330). Finally, there exists among some Evangelical and Catholic leaders what I would call a moral framing of disaffiliation, where opting out of religion is presumed not so much to be a practical problem in need of a solution as the manifestation of serious moral dangers and struggles in the larger society.

To further examine this last way of framing disaffiliation, I turn to the work of the Catholic bishop and theologian Robert Barron. My aim here is theoretical, to consider an example of the thinking that undergirds this moral framing of disaffiliation rather than the important empirical task of measuring its reach or categorizing its most frequent manifestations. Bishop Barron describes himself primarily as an evangelizer, and he has addressed the phenomenon of disaffiliation on occasions too numerous to catalogue. In late 2019, he addressed his fellow bishops on the topic (Clemmer 2019). At the same time, Barron has long established himself as a successful writer and media entrepreneur with a tremendous reach. Even before his well-known documentary series Catholicism aired on PBS in 2011, he had a history working in radio and television, and the comprehensive media platform he founded in 2000, Word on Fire, initially to publish his homilies, now boasts an annual revenue that in 2018 exceeded three million dollars (Clemmer 2019). As of the spring of 2021, Barron had more than 175,000 people following him on Twitter, over three million on Facebook, and his YouTube channel had 420,000 subscribers. I choose him both because he identifies as an expert on this issue, who has laid out his thinking on it clearly, and also because of his considerable influence.

Long before Barron reached this level of influence, he was known as an intellectually minded critic of the project of liberal Catholicism after the Second Vatican Council. Referring to it as "beige Catholicism", Barron spoke of "a faith that had become culturally 
accommodating, hand-wringing, unsure of itself; a Church that had allowed its distinctive colors to be muted and its sharp edges to be dulled" (Barron 2021). A rapprochement with particular strains of modern secular culture-those emphasizing freedom as autonomy, the privatization of belief and value, and a Hobbesian view of the human person as little more than a self-interested brute-had in a sense contaminated and marginalized the liberal Catholic project (Barron 2020c, pp. 249-53). Looking back to the great (European and Euro-American) intellectual lights of mid-twentieth-century Catholic literature, philosophy, and theology, Barron pines for that era's intellectual rigor and confidence, and thus the power of Catholicism as a counter-cultural witness to the aforementioned worst aspects of post-Enlightenment liberalism (Barron 2020c, p. 26).

Barron sees Western societies as now steeped in a fundamental hostility to religion. Like other conservative American intellectuals, Barron identifies this aggressive antireligious secularism with the universities and with exponents of postmodernism (chiefly understood by Barron as the proponents of critical theory). ${ }^{9}$ It enables a radically individualistic, morally relativistic "culture of self-invention":

How often do we hear especially young people taunt anyone who would lay out a program to inform their freedom: "Who are you to tell me how to think or how to behave?" For many in our culture today, ancient traditions of behavior, inherited patterns of meaning, and especially religious values and intuitions appear simply as arbitrary impositions on the self-legislating and self-inventing ego. (Barron 2020c, p. 251)

To Barron, this hostile secularism is nowhere better represented than in the intellectual influence of the New Atheists-a group of popular atheist scientists and journalistson young people: "Armies of them have been argued into the position of nonbelief or agnosticism by the aggressive evangelism of the new atheists" (Barron 2020c, p. xii).

This influence is only possible, Barron argues, because of the anti-intellectualism of Catholic pastoral leaders after Vatican II, who "dumbed down the faith" in their fervor to make it accessible, leaving young people intellectually defenseless against the secular tide. While pushing for a renewed intellectually rigorous apologetics, Barron also recommends that pastoral leaders begin not with a focus on truth or morality, but on beauty: "In our radically relativistic time, it does seem advisable to commence the evangelical process with the winsome attractiveness of the beautiful, and thank God, Catholicism has plenty to offer in this regard" (Barron 2020c, p. 25). The moral relativism of Western societies and the influence of academic elites in promoting it have made aesthetics a much more promising starting point for evangelization (Barron 2020c, pp. 21-29).

In intellectual debate, one could, of course, take issue with different aspects of Barron's argument, from his convictions about liberal Catholicism as anemic to his analysis of the dangerous influence of secular liberalism without the moral foundation of religion to his allegations regarding anti-intellectualism in Catholic religious education. My interest, instead, is in how Barron's thinking illustrates a moral framing of disaffiliation. The exodus of young people out of religion is, in Barron's view, a victory for secular (and often aggressively atheist) elites promoting individualism, relativism, and the wrong-headed idea that identity is a product of self-invention alone. To Barron, the practical ecclesial problem of emptying pews is less the issue than the accompanying inevitable moral decline as people turn away from the ancient traditions that sustain them as good moral actors in society and keep the corruption of modern ideals at bay.

\section{The Sociology of Moral Regulation}

Insofar as theological opponents take notice of Barron's ideas and arguments at all, they usually take issue with the conservative ideological assumptions undergirding them. ${ }^{10}$ Instead I argue that we should take Barron's ideas seriously as an influential example of a particular kind of modern public argument. At the same time, that kind of public argument may not be terribly responsive or effective in the face of disaffiliation. In order to understand 
what Barron is up to in this moral framing of disaffiliation, I turn to a set of theoretical lenses that have emerged in the sociology of social problems over the last few decades.

In the 1970s, sociologists reacted to then-current explanations for social problems (especially among criminologists) that emphasized deviance. These new theorists of social problems observed that such an emphasis risked overlooking entirely the social structures and processes behind social problems like crime. These new efforts grew in part out of a shift in epistemology in sociology, the emergence of social constructionism. Social constructionists rejected a naïve objectivity about the social world and asked questions about the way people frame (or construct) the external reality they encounter. ${ }^{11}$ Most social constructionists were not "strict constructionists", that is, committed relativists who eschew all truth claims; instead, they were "contextual constructionists" who argued that how we think about reality has real and significant consequences for social life. ${ }^{12}$

In other words, there are many possible ways of framing or constructing a social problem like disaffiliation, and various actors might be involved in applying a particular interpretive lens. One class of these actors, according to sociologist Howard Becker, was what he called moral entrepreneurs, actors outside the state who devote themselves in innovative and public ways to moral reform-“organizers, activists, do-gooders, movement advocates who push for a given cause" (Goode and Ben-Yehuda 1994, p. 20). Moral entrepreneurs gained greater attention in sociology after a seminal 1972 book by sociologist Stanley Cohen, a political exile from South Africa. Cohen coined the term moral panic using a case study about British media overreaction to a 1964 civil disturbance in an English seaside resort town. ${ }^{13}$ "Cohen launched the term moral panic as a means of characterizing the reactions of the media, the public, and agents of social control [i.e., police] to the youthful disturbances" (Goode and Ben-Yehuda 1994, p. 24). According to Cohen, the moral panic relied in part upon dire predictions by moral entrepreneurs regarding the ultimate outcome of such civil disturbances should the underlying moral threat of lawless youth not be addressed (Critcher 2015, pp. xviii-xix). In short, moral entrepreneurs helped to popularize a decidedly moral framing of the social problem of youth rebellion in a way that contributed to the frenzied reaction to it.

The moral panic part of Cohen's theory caught the attention of both sociologists and media analysts in the ensuing decades. "The concept soon spread far beyond academia until it became common in Britain's popular media" (Best 2013, p. 68). Scholars and journalists, both in Britain and eventually in the United States, began to use moral panic as a kind of shorthand for debunking any exaggerated public concern. In any case, the resulting frenzy of attention led some sociologists to reject the term entirely, or to severely limit its use. ${ }^{14}$ Others developed aspects of Cohen's theory in a slightly different direction, including the sociologist Sean Hier, who saw moral panic as a less frequent manifestation of larger sociological processes of moral regulation.

According to Hier, in the absence of undisputed guidance over moral behavior from religious institutions or other moral authorities, pluralistic modern communities struggle over how to regulate moral behavior in society (Critcher 2015, pp. xxxi-xxxii). Value conflicts erupt between groups. As the conflict intensifies, people frame more and more of everyday life in moral terms: "A growing number of everyday activities become moralized in the form of dialectical judgments about what is right and wrong" (Hier 2011, p. 9). People begin to see activities that previously were assigned little serious moral value, such as punctuality or exercise, as indicators of moral character (or of moral decline). Under the sway of the neoliberal economy's emphasis on individual responsible behavior, moral entrepreneurs lionize individual responsibility, risk management, and self-care, but at the same time juxtapose it to "collective representations of 'harmful others.'" (Hier 2011, p. 9) In short, such actors motivate people to individual moral regulation in part by the creation of a symbolic group of offenders who represent the consequences of bad behavior. Hier presents the amusing example of moral entrepreneurs promoting exercise as an individual discipline of health, but notes that they generally do so in part by disparaging "couch potatoes" (Hier 2011, pp. 9-10). One might similarly point to "fat shaming" as part of 
moral entrepreneurs' efforts to encourage not only exercise but also particular diets or food regimes as morally upright healthy behavior.

In short, moral regulation as a long-term social project deals with value conflicts in a pluralistic society in part via attempts at moralization, which Hier sees as a rational sociological process by which groups attempt to get other groups, usually perceived as moral deviants in some way, to change their ways (and, in the process, recognize the moral entrepreneur's unique moral authority). Moral panics then become short-term crises amidst these longer-term processes of moral regulation. In such crises, in the eyes of moral entrepreneurs, moral regulation has failed; moral deviants refuse to listen, and thus must be dramatically reclassified as folk devils, as a "threat to the moral or material well-being of moral entrepreneurs" (Hier 2011, p. 10).

\section{Discussion}

Both social constructionism in general and moral regulation theory in particular prove fruitful in helping us understand the moral framing of disaffiliation by Catholic "moral entrepreneurs" like Robert Barron. For example, moderate social constructionists in sociology invite us to critically examine how disaffiliation is imagined or constructed. Is it an opportunity or a problem? Is it a historical development spurred by specific events, or is it a larger manifestation of moral crisis or decline? The moral framing of disaffiliation sees religious affiliation as a normative and salutary human behavior. Disaffiliation constitutes not only a social problem for religious communities but a moral problem for all of society. According to Barron's thinking, for example, disaffiliation manifests the negative influence of secular liberalism promoting radical autonomy, emboldened by the marginalizing privatization of religion and the "beige" anemia of religious institutions like the Catholic Church in the United States in its culture-accommodation phase, after the Second Vatican Council.

According to Hier's theoretical argument, moral entrepreneurs like Barron are engaged in a very public form of value conflict. Indeed, it seems clear that Barron hopes to persuade other Catholics to recognize the urgency of the moral danger in the individualistic notion of "self-invention" popular among young people, as well as other forms of secular thinking that emphasize radical autonomy and disconnection from the moral authority of religious traditions. We might even describe his brand of moral entrepreneurship as unusually intellectually driven. For Barron as a theologian, influential bad ideas are a wellspring for moral evil, and they are best countered by responsible and morally robust good ideas. Each Catholic should distance from the bad (secular) thinking and embrace the good, which Barron identifies with traditional Catholicism, but also with Enlightenment political theory shorn of certain secular excesses. ${ }^{15}$ In pushing for this distancing, just as Hier's approach predicts, Barron makes a plea for individual moral responsibility but also presents a moral "other", embodied specifically by academics attending to critical theory and liberal Catholic leaders who have enervated postconciliar Catholicism. Finally, while Barron is a Catholic bishop, invested with a traditional kind of moral authority, his persuasive authority in this effort comes more from his role as a prominent media innovator and public personality-a moral entrepreneur.

When we analyze Barron's thinking in this sociological register, we see certain things with clarity. This moral framing of religious disaffiliation has a great deal more to do with these larger social projects of moral regulation than with the historical phenomenon of disaffiliation since the 1990s. Moral entrepreneurs like Barron borrow or appropriate disaffiliation for what they see as a greater moral purpose. In a sense, this is the genius of Bishop Barron. With his pulse on the anxiety generated for Catholics by disaffiliation, he proposes a bold strategy for the moral order of U.S. society, which he sees as threatened by the marginalization of religious institutions and the rise of a secular liberalism that lionizes individual autonomy. In making such an argument, of course, he relies not simply on the intellectual force of his argument, but upon his own status and reach as a media entrepreneur and as a bishop. In the end, disaffiliation plays only a narrow role here; it functions principally as a symptom of a larger moral struggle. 
Yet as our review of the research on disaffiliation suggests, the dramatic rise of religious disaffiliation since 1990 is not easily understood in terms of a larger moral struggle-either in terms of glacial processes of secularization or as a result of increasing personal autonomy across society. The cultural dominance of freedom as "self-invention" and the privatization of religion that Barron references were both well underway long before 1990. The specific phenomenon of young people opting out of religion since the 1990s simply cannot be reasonably attributed to these longer-term processes. Religious disaffiliation remains better understood as a generational exodus initially precipitated by religious groups staking out public positions on specific controversial issues. That exodus now seems to have a momentum of its own. Certainly, disaffiliation relies on a strong enough sense of personal autonomy for a person to feel free to overrule traditional religious loyalties (and perhaps a weaker sense of those loyalties). For much of Western history, most people likely did not feel free to do this, to choose no religion. But in the United States, at least since the Deist era of the American Enlightenment, it has been an imaginable option to opt out, and such figures as Thomas Paine, Thomas Jefferson, Ralph Waldo Emerson, and Abraham Lincoln availed themselves of it.

Indeed, since the religious disestablishment in the United States in the late 1700s, all religious affiliation has had a voluntary element to it, even in religious groups that emphasize inherited identity, such as Jews or Catholics. ${ }^{16}$ What has fluctuated has been the social pressures toward or away from religious affiliation and commitment, either generally or to specific groups, usually in response to historical circumstances. During the Second Great Awakening in the first half of the nineteenth century, the social pressure to affiliate increased dramatically, but the most attractive options for such affiliation also changed, so that Southern states previously filled with Episcopalians ultimately turned Baptist. After the anti-institutional social critiques of the late 1960s, the social pressure to affiliate religiously began to wane from its postwar heights in the 1950s, but not so much that masses of people opted out. However, it seems clear that social pressure against religious affiliation increased dramatically in the 1990s, apparently in response to very public campaigns by religious leaders on controversial political issues. According to the research, strong stands by prominent religious groups against same-sex marriage played an outsized role in younger generations wishing to distance themselves from religion.

Taking the long view, however, there is no reason to assume that this particular wave of disaffiliation has become a permanently progressive phenomenon, as a moral framing of disaffiliation often presumes. There is a pleasing moral urgency in organizing opposition to powerful (secularizing) forces poised to destroy religion forever. Yet the now-debunked secularization consensus in sociology once presumed that secular modernity would inevitably lead to the death of religion everywhere, something which categorically has not occurred. While disaffiliation appears poised to take a heavy toll on religious institutions in the short or even medium term, concerns that Catholicism or any other religious tradition is "dying out" in the U.S. context seem decidedly premature. Disaffiliation in American life is a product of specific historical circumstances rather than an inevitable secularizing progression. Accordingly, the long-term future of faith in the United States, including Catholic faith, cannot be foreseen with any accuracy. We simply do not know what social pressures will arise to swing for or against religious affiliation in the future and why.

\section{Conclusion: A Historical-Pastoral Framing of Disaffiliation}

The moral framing of disaffiliation serves moral entrepreneurs. As sociologist Sean Hier notes, in a world without consensus as to who constitutes a moral authority or what moral values should predominate, moralizing discourse has a powerful hold on people's imagination. It can feel necessary, even a matter of the survival of one's moral tribe. To avoid moralizing can seem like surrender, or even a tacit endorsement of societal evils. At the same time, the sociological research on disaffiliation points to a mismatch between this moral framing and the historical roots and social processes that have resulted in young people opting out. In fact, given the role that religious groups taking political 
positions has played in precipitating religious disaffiliation, a strong moral framing may actually exacerbate the problem. Again, if the purpose is to take an unambiguous moral stand amidst larger moral struggles in society, that may not matter. But religious leaders who honestly and practically wish to tackle disaffiliation as a pastoral challenge for their communities should consider dispensing with a moral framing and turn instead to what I call a "historical-pastoral" framing of disaffiliation. This construction of the phenomenon recognizes its roots in specific historical circumstances and views it simply as a sign of the present times, worthy of sustained pastoral attention. It is a pastoral challenge for religious leaders rather than a marker of a grand societal moral struggle.

On the most practical level, this historical-pastoral framing argues for prudent preparations in terms of the size and types of religious institutions faith communities need for the foreseeable future. Some aging local faith communities and religious organizations will certainly die out, and it seems wise to make provision for that, both in terms of responsible pastoral care for older members and plans to make different use of facilities. Other parishes, congregations, and organizations will persevere but at a smaller size. We may see a lot of fluctuation in other sectors of the religious landscape, especially those attempting to innovate, where trends may catch on for a while and then play themselves out. Some communities or organizations may wish to tweak their mission to provide spiritual services of some sort to those other than their formal members. In short, religious institutions should accept disaffiliation as a dramatic present reality and adjust their footprint and plans accordingly.

A historical-pastoral framing also invites pastoral leaders to keep in mind the generational momentum of disaffiliation. A kind of "preferential option for the young" may be in order, given that the phenomenon is driven by younger generations, though it is not exclusive to them. ${ }^{17}$ Pastoral leaders will perhaps devote time and energy to accompanying and listening to groups of younger unaffiliated persons. Rather than starting with moral instruction or apologetics, they might ask, "Tell me about what pain, what fears, what doubts brought you to this point", and then demonstrate an equal willingness to share their own pain, fears, and doubts. Once this relationship is established, once this accompaniment has begun, there is perhaps good reason to follow Robert Barron's advice about approaching the journey of faith from the aesthetic. This would not be a concession to moral relativism, as it is for Barron, but instead a promising starting location for dialogue about the transcendent, especially if some of the young dialogue partners do not see that transcendent as necessarily an expression of divine mystery.

The historical-pastoral framing also asks pastoral leaders to grapple honestly with the specific historical factors that shaped disaffiliation beginning in the 1990s, especially many churches' strong embrace of opposition to state recognition of LGBTQ rights, and opposition to same-sex marriage. Even after the 2015 U.S. Supreme Court decision in Obergefell v. Hodges recognized the civil marriage of same-sex couples as a fundamental right and settled the matter legally, the memory of opposition lingers. In his book for parents of the disaffiliated, Brandon Vogt, Senior Content Director for Barron's Word on Fire ministries, acknowledges this poignantly:

A few years ago, a collection of national surveys revealed that the most common perception of present-day Christianity is "anti-homosexual". This means that the first thing people think of when encountering a Christian is not what they're for but what they're against. And in the eyes of most people, they're against gays and lesbians. This is a huge problem. Not only does this stand against Jesus' own teachings - he was never anti-anyone-it presents a serious barrier for those who have left the Church. Even if your child finds many other strong arguments in favor of returning to the Church, this one issue alone could keep him away. (Vogt 2021, pp. 158-59)

While a strong attachment to biblical inerrancy among Evangelicals and to the scholastic natural law moral tradition among some Roman Catholics makes it impossible for many religious leaders to countenance any change in teaching, even many conservative religious 
leaders today have shifted away from heated moralizing on the subject. Vogt urges parents not to begin by criticizing their children's lifestyles. "Pope Francis has spoken against this hyper-moralizing strategy" (Vogt 2021, p. 38). Pastoral strategies that emerge from the historical-pastoral framing will not hesitate to confront the centrality of this political issue in the history of disaffiliation since the 1990s, and are less likely to resort to moralizing when they do.

Framing disaffiliation as a pastoral challenge with discrete historical roots allows pastoral leaders to move beyond constructing it as the outcome of some inevitable immoveable societal force. The latter interpretation often leads to fatalism-giving up entirely on pastoral outreach among the young. This seems entirely unwarranted since as of this writing a majority of young people still identify as religious in some way. It can also breed a certain degree of resentment among those who have devoted their lives to participating in their own faith community and serving the church in different ways. Both fatalism and resentment get in the way of what is perhaps the churches' best way forward in terms of pastoral practice-authentic hospitality. If the momentum of disaffiliation among the young is in part the product of a strong perception by young people that either they themselves or their LGBTQ friends or family members were unwelcome, then hospitality as a public ecclesial practice serves as a powerful tool to signal something different. What if the church became known as a place where anyone could find a welcome to enter and confront the biggest existential questions of life in communion with others? What if, instead of people first associating Christian churches with being anti-gay, they associated churches with practices of welcome, habits of listening, and with creating an open space to lay down one's burdens and make sense of one's life?

Funding: This research received no external funding.

Conflicts of Interest: The author has no conflict of interest.

\section{Notes}

1 See, for example, (Manning 2018).

2 See (Finke and Stark 2005, p. 23). Though Finke and Stark's embrace of the explanatory power of the religious "marketplace" has met with significant criticism because of its dependence on individualistic rational choice notions of human decision making, fewer sociologists or social historians dispute that church attendance has varied a great deal through US history.

3 (Burge 2020). Ryan Burge argues that the significant difference in survey results can be attributed to the difference in how very weakly affiliated Protestants respond to the particular instrument. In one survey, they are more likely to call themselves Protestant but in another not religious.

4 According to recent Pew Research Center data, as many as a third of Black millennials or GenZers identify as having no religion. (Mohamed et al. 2021).

5 See, for example, (Streib 2021). For a more theological account, see (Hornbeck 2012).

6 (Heft and Stets 2021, p. 3). See also (Hout and Fischer 2002, pp. 169-72).

7 See, for example, (Ellison and Lee 2010; Vargas 2012).

$8 \quad$ See (Manning 2018, pp. 36-37).

9 See, for example, (Barron 2020a, 2020b).

10 See, for example, (Faggioli 2021) or (Shadle 2019).

11 Social constructionism in sociology parallels the application of hermeneutical theory in theology or philosophy beyond ancient texts to reality itself as a "text".

12 (Hier 2011, pp. 7-8). See also, (Goode and Ben-Yehuda 1994, pp. 94-100).

13 (Goode and Ben-Yehuda 1994, pp. 22-23). See also (Cohen 1972).

14 (Best 2013, p. 76). See also (Hier 2011, pp. 1-3).

15 See, for example, (Barron 2020c, pp. 242-53).

16 See (Warner 1993, p. 1014 n. 10; Warner 2000, pp. 276-79).

17 The phrase was first used at the 1979 Puebla meeting of the Latin American Catholic Bishops' Conference (CELAM, in Spanish and Portuguese). See (Conferencia del Episcopado Latinoamericano CELAM, nos. 1166-205). 


\section{References}

Alper, Becka A. 2018. From the Solidly Secular to Sunday Stalwarts. Fact Tank, Pew Research Center. August 29. Available online: https:/ / www.pewresearch.org/fact-tank/2018/08/29/religious-typology-overview/ (accessed on 30 March 2021).

Ammerman, Nancy T. 2021. The Many Meanings of Non-Affiliation. In Empty Churches: Non-Affiliation in America. Edited by James Heft and Jan Stets. New York: Oxford University Press.

Barron, Robert. 2020a. 'Culture Warrior' and the Fallacy of Misplaced Concreteness. World on Fire Website, December 29. Available online: https:/ / www.wordonfire.org/resources/article/culture-warrior-and-the-fallacy-of-misplaced-concreteness/29382/ (accessed on 30 March 2021).

Barron, Robert. 2020b. Acknowledging an Abyss, Finding a Bridge. Word on Fire Website, September 22. Available online: https: //www.wordonfire.org/resources/article/acknowledging-an-abyss-finding-a-bridge/28601/ (accessed on 30 March 2021).

Barron, Robert. 2020c. Renewing Our Hope: Essays for the New Evangelization. Washington, DC: The Catholic University of America Press.

Barron, Robert. 2021. The Evangelical Path of Word on Fire. Word on Fire Website, March 2. Available online: https:/ /www.wordonfire. org/resources/article/the-evangelical-path-of-word-on-fire/30079/ (accessed on 19 May 2021).

Beaudoin, Tom. 2013. Teaching Theology in an Atmosphere of Deconversion. Horizons 40: 255-62. [CrossRef]

Best, Joel. 2013. The Problem with Moral Panic: The Concept's Limitations. In The Ashgate Research Companion to Moral Panics. Edited by Charles Krinsky. New York: Routledge.

Burge, Ryan P. 2020. How Many Nones Are there? Explaining the Survey Discrepancies. Review of Religious Research 62: 173-90. [CrossRef]

Conferencia del Episcopado Latinoamericano (CELAM). 1979. Mensaje a los Pueblos de Latinoamérica. Documento de Puebla III Conferencia General del Episcopado Latinoamericano. Available online: http:/ / www.celam.org/doc_conferencias/Documento_ Conclusivo_Puebla.pdf (accessed on 19 May 2021).

Clemmer, Don. 2019. Evangelizing Young 'Nones' Is Bishop Barron's Brand. National Catholic Reporter, November 4. Available online: https:/ / www.ncronline.org/news/people/evangelizing-young-nones-bishop-robert-barrons-brand (accessed on 19 May 2021)

Cohen, Stanley. 1972. Folk Devils and Moral Panics: The Creation of the Mods and Rockers. London: MacGibbon and Kee.

Critcher, Charles. 2015. Commentary: Moral Panics Yesterday, Today, and Tomorrow. In Revisiting Moral Panics. Edited by Vivienne E. Cree, Gary Clapton and Mark Smith. Bristol: Bristol University Press.

Dillon, Michele. 2018. Postsecular Catholicism: Relevance and Renewal. New York: Oxford University Press.

Ellison, Christopher G., and Jinwoo Lee. 2010. Spiritual Struggles and Psychological Distress: Is There a Dark Side of Religion? Social Indicators Research 98: 501-17. [CrossRef]

Faggioli, Massimo. 2021. Bishop Robert Barron's ‘Beige' Version of Vatican II. National Catholic Reporter, May 14. Available online: https:/ / www.ncronline.org/news/opinion/bishop-robert-barrons-beige-version-vatican-ii (accessed on 19 May 2021).

Finke, Roger, and Rodney Stark. 2005. The Churching of America, 1776-2005: Winners and Losers in Our Religious Economy. Piscataway: Rutgers University Press.

Goode, Erich, and Nachman Ben-Yehuda. 1994. Moral Panics: The Social Construction of Deviance. Cambridge: Blackwell.

Heft, James, and Jan Stets, eds. 2021. Empty Churches: Non-Affiliation in America. New York: Oxford University Press.

Hier, Sean P., ed. 2011. Moral Panic and the Politics of Anxiety. New York: Routledge.

Hornbeck, J. Patrick, II. 2012. Deconversion: What, Who, Why, How? Horizons 40: 262-74. [CrossRef]

Hout, Michael, and Claude S. Fischer. 2002. Why More Americans Have No Religious Preference: Politics and Generations. American Sociological Review 67: 165-90. [CrossRef]

Hout, Michael, and Claude S. Fischer. 2014. Explaining Why More Americans Have No Religious Preference: Political Backlash and Generational Succession, 1987-2012. Sociological Science 1: 423-47. [CrossRef]

Manning, Christel J. 2015. Losing Our Religion: How Unaffiliated Parents Are Raising Their Children. New York: NYU Press.

Manning, Patrick R. 2018. Disintegrating Worldviews and the Future of Catholic Education: Addressing the Deep Roots of Catholic Disaffiliation. Journal of Catholic Education 21: 26-50. [CrossRef]

Mohamed, Besheer, Kiana Cox, Jeff Diamant, and Claire Gecewicz. 2021. Faith among Black Americans. February 16. Available online: https:/ / www.pewforum.org/2021/02/16/faith-among-black-americans / (accessed on 30 March 2021).

Nagle, James Michael. 2019. The Thinker and the Guide: A Conversation Concerning Religious Disaffiliation from the Catholic Church. Journal of Ecumenical Studies 54: 328-51. [CrossRef]

Pew Research Center. 2015. America's Changing Religious Landscape. Washington, DC: Pew Research Center.

Pew Research Center. 2018. Why America's Nones Don't Identify with a Religion. Fact Tank, Pew Research Center. August 18. Available online: https://www.pewresearch.org/fact-tank/2018/08/08/why-americas-nones-dont-identify-with-a-religion/ (accessed on 30 March 2021).

Pew Research Center. 2019. In U.S., Decline of Christianity Continues at Rapid Pace: An Update on America's Changing Religious Landscape. Washington, DC: Pew Research Center.

Putnam, Robert D., and David E. Campbell. 2010. American Grace: How Religion Divides and Unites Us. New York: Simon \& Schuster.

Shadle, Matthew A. 2019. Bishop Robert Barron on the Appeal of Marxism. Political Theology Network, August 16. Available online: https:/ / politicaltheology.com/bishop-robert-barron-on-the-appeal-of-marxism/ (accessed on 19 May 2021).

Streib, Heinz. 2021. Leaving Religion: Deconversion. Current Opinion in Psychology 40: 139-44. [CrossRef] [PubMed] 
Streib, Heinz, Ralph W. Hood Jr., Barbara Keller, Rosina-Martha Csöff, and Christopher F. Silver. 2009. Deconversion: Qualitative and Quantitative Results from Cross-Cultural Research in Germany and the United States of America. Göttingen: Vandenhoeck \& Ruprecht. Vargas, Nicholas. 2012. Retrospective Accounts of Religious Disaffiliation in the United States: Stressors, Skepticism, and Political Factors. Sociology of Religion 73: 200-23. [CrossRef]

Vogt, Brandon. 2021. Return: How to Draw Your Child Back to the Church. Park Ridge: Word on Fire.

Warner, R. Stephen. 1993. Work in Progress toward a New Paradigm for the Sociological Study of Religion in the United States. The American Journal of Sociology 98: 1044-93. [CrossRef]

Warner, Stephen R. 2000. Religion and New (post-1965) Immigrants: Some Principles Drawn from Field Research. American Studies 41: $267-86$. 